\title{
Recruitment variation in sympatric populations of Haliotis rubra (Mollusca: Gastropoda) in southeast Australian waters
}

\author{
P. E. McShane*, M. G. Smith \\ Marine Science Laboratories, Department of Conservation and Environment, Queenscliff, Victoria, Australia
}

\begin{abstract}
Recruitment of abalone Haliotis rubra was examined in sympatric populations off southeastern Australia soon after the main spawning period. The size range of post-settlement juveniles (recruits) collected from the reef surface was indicative of recent settlement. Recruitment was strongest after the main spawning period but episodic minor recruitment in some populations was also observed throughout each year. Recruitment varied significantly both between populations and for each population over time; the latter varied over 3 orders of magnitude. The highest number of $H$. rubra recruits in a sample (the area contained within a $1 \mathrm{~m}^{2}$ quadrat) was 12456 . Abalone larvae can settle in densities much higher than has previously been assumed. Localised dispersal of larvae provides an explanation for our results. Variability in recruitment of $H$. rubra was high even when the density of the adult population was constant.
\end{abstract}

\section{INTRODUCTION}

Studies of benthic invertebrate communities in marine habitats have emphasized the importance of variations in recruitment in determining the distribution and abundance of adults (Denley \& Underwood 1979, Underwood \& Denley 1984, Caffey 1985, Connell 1985, Lewin 1986, Gaines \& Roughgarden 1987). These studies have largely been concerned with intertidal species such as barnacles, but more recently an increasing emphasis on the early life history of benthic marine invertebrates has prompted investigation of other groups of invertebrates from subtidal habitats including sea urchins (Rowley 1989), holothuroids (Young \& Chia 1982), ascidians (Davis 1987, 1988, Young 1989, Stoner 1990), corals (Gerrodette 1981), polychaetes (Hannan 1984, Butman 1987, 1989, Duggins et al. 1990); bryozoans (Yoshioka 1982, 1986, Keough 1983, 1986, Duggins et al. 1990), and gastropods (Fletcher 1987, McShane et al. 1988).

Although the studies cited above provide a clearer understanding of recruitment processes in populations of benthic invertebrates within a broad phylogenetic

- Present address: MAF Fisheries Greta Point, PO Box 297. Wellington, New Zealand framework, the sources of variation in recruitment for many species remain obscure. Only for those species with large larvae (some larvae of corals and ascidians) can dispersal and settlement be observed in situ (e.g. Gerrodette 1981, Davis 1988, Stoner 1990). Consequently conclusions drawn from such studies have been criticised as being unrepresentative of recruitment patterns in benthic species (e.g. Keough 1989) and may have little relevance for most taxa with microscopic pelagic larvae. Settlement patterns and the extent of larval dispersal of benthic marine invertebrates are most often inferred by observing recruitment - recruitment being the stage in the life history of a species when individuals are large enough to be observed. Often considerable time elapses between settlement and observations of recruits (Keough \& Downes 1982). The repercussions of differential mortality can be such that recruitment may be unrelated to settlement (Keough \& Downes 1982, Connell 1985, McGuinness \& Davis 1989, McShane 1991a). A poor understanding of post-settlement mortality contributes to the unreliability of many studies of recruitment in marine benthic invertebrates (McGuinness \& Davis 1989).

Haliotis rubra is a commercially exploited gastropod common on sublittoral reefs off southeastern Australia (Shepherd 1973, McShane et al. 1986, 1988). We show 
here that the measurement of recruitment in the abalone $H$. rubra shortly after settlement can provide information on factors influencing settlement and provide clues as to the source of recruitment variation.

\section{MATERIALS AND METHODS}

Location. We studied recruitment of Haliotis rubra populations off Mallacoota and Portland in southeastern Australia (Fig. 1). These populations were chosen because they are important commercially (McShane et al. 1986) and because they provided an opportunity to examine recruitment in differing habitats in disparate locations within the distributional range of the species. The regional physiographic characteristics off Mallacoota, including a description of the hydrodynamics, have been described by McShane et al. (1988) and Black \& McShane (1990). Whereas populations of $H$. rubra at Mallacoota inhabit low relief basalt reefs, populations off Portland inhabit high relief limestone reefs in communities dominated by the kelp Phyllospora comosa. Moreover, the coast off Portland is often exposed to heavy southwest waves; the coast off Mallacoota is generally less exposed (Black \& McShane 1990). Recruitment surveys at all locations were undertaken on the rocky substratum in a depth range of 6 to $10 \mathrm{~m}$.
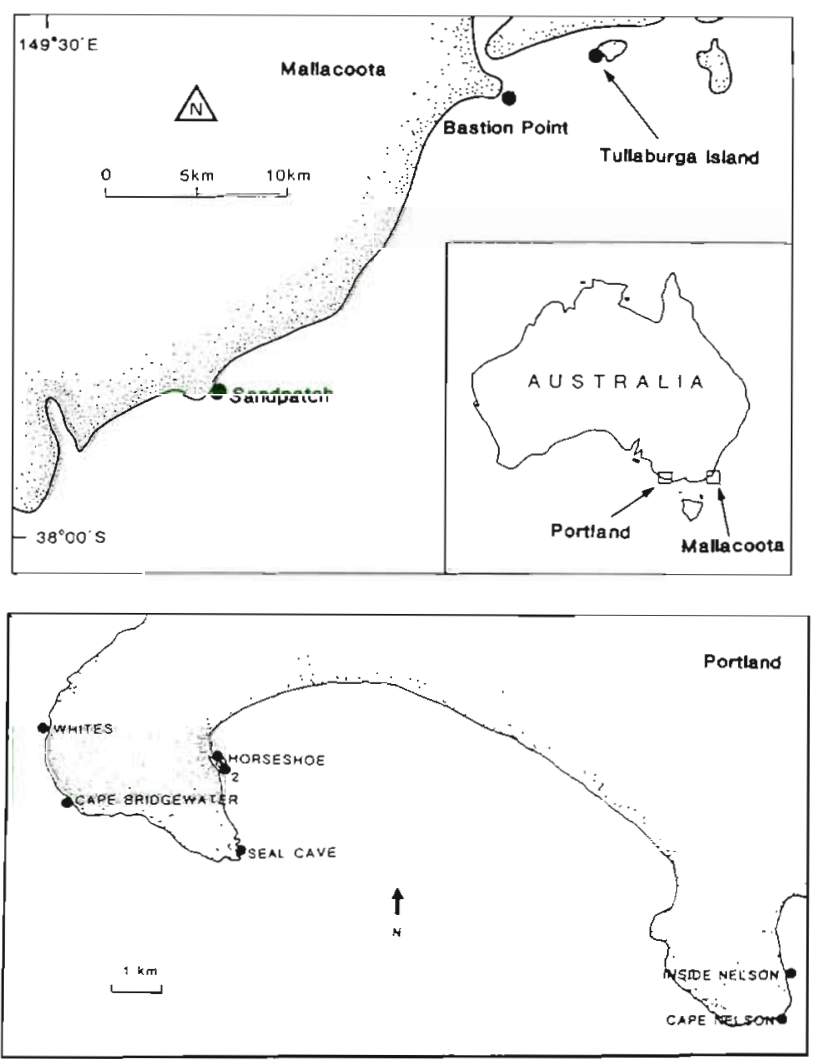

Fig. 1. Sample site locality
Recruitment. Surveys of Haliotis rubra recruits were undertaken on each of 6 occasions for each of 3 populations off Mallacoota; Sandpatch, Tullaburga Island and Bastion Point (during February, May, August and December 1987. December 1988, and January 1989). Sample sites were as described in McShane et al. (1988). Surveys of $H$. rubra recruits were also undertaken off Sandpatch during December 1989. Similar surveys were undertaken off Portland during December 1989 (Fig. 1).

At each site, 5 replicate $1 \mathrm{~m}^{2}$ quadrats were randomly placed on the reef surface. Thus, areas of high prevalence of coralline algae were not targetted. However, surveys revealed that coralline cover on the reefs off Mallacoota and Portland ranged from 10 to $80 \%$ (P. E. McShane unpubl; see also McShane et al. 1988). In each quadrat, we used our venturi-suction method (McShane \& Smith 1988) to sample recruits of Haliotis rubra. The method allows for collection of all postsettlement recruits (>ca $300 \mu \mathrm{m}$ ) up to ca $12 \mathrm{~mm}$ in shell length. Larger individuals can be easily seen and collected by divers (McShane 1991a). The sorting of $H$. rubra from other biota and debris typically entrained in a sample was enhanced by the use of a $0.1 \%$ solution of rhodamine $B$ dye, which makes the tiny recruits more conspicuous (Hamilton 1969), and the separation method of Sellmer (1956) where $\mathrm{ZnCl}_{2}$ is used to increase the specific gravity of a solution containing an epibenthic sample. Animals with a calcareous shell, such as $H$. rubra recruits, float when $\mathrm{ZnCl}_{2}$ is added and can be separated from the other epibenthic material. Thus the mean sorting time per sample was reduced from 19 to $3 \mathrm{~h}$. Recruits of $H$. rubra collected from each sample were counted and the shell length of each was measured to the nearest $10 \mu \mathrm{m}$ under a binocular microscope.

Population density. Population densities of Haliotis rubra were measured only off Mallacoota. Surveys in December of each year were used to estimate the density of adults. On each occasion at each location, divers collected all $H$. rubra in 3 randomly located transects consisting of 50 contiguous $1 \mathrm{~m}^{2}$ quadrats as described by McShane et al. (1988). All H. rubra collected were counted and the shell length of each was measured to the nearest millimetre. Small cryptic individuals $(<20 \mathrm{~mm}$ ) tend to be undersampled by searching but the method provides reasonable estimates of adult density (McShane et al. 1988, McShane 1991a).

\section{RESULTS}

The recruits of Haliotis rubra sampled in our surveys ranged in length from 320 to over $3000 \mu \mathrm{m}$. Our lengthfrequency results can be used to estimate and compare 
the timing and relative synchrony of settlement between populations. At settlement, an abalone larva is ca $350 \mu \mathrm{m}$ in length (Ino 1952, McShane unpubl. data for $H$. rubra). Data from Garland et al. (1985) indicate the post-settlement growth rate of $H$. rubra to be ca 10 $\mu \mathrm{m} d^{-1}$. Thus the length of the smaller recruits sampled in our study was indicative of recent settlement.

\section{Mallacoota}

Analysis of variance indicated that the mean density of recruits was similar between sites at each of the 3 locations, Sandpatch, Tullaburga Island and Bastion Point ( $p>0.2$ ). An exception was for Haliotis rubra recruits sampled from Tullaburga Island during December 1988 where there was a significant difference in density between sites $\left(F_{1,8}=7.4, \mathrm{p}=0.03\right)$ Data were pooled in all other cases for comparison of recruitment between populations and over time by 2-way ANOVA.

During 1987, when samples were taken throughout the year, recruits were present on each occasion for each of the 3 populations Sandpatch, Tullaburga Island and Bastion Point (Fig. 2). However, in general the length-frequency results indicated that there was only one main period of recruitment extending over December and January. An exception was for the population at Bastion Point where substantial recruitment occurred during May (a distinct mode of recently settled individuals was apparent; mean density $\pm \mathrm{SE}$ : $93 \pm 47 \mathrm{~m}^{-2}$, mean length $450 \pm 32 \mu \mathrm{m}$ ) and minor recruitment was observed in August (mean density \pm $\mathrm{SE}: 5 \pm 3 \mathrm{~m}^{-2}$, mean length $1.1 \pm 0.6 \mathrm{~mm}$; Fig. 2).

The mean lengths of recruits sampled in December were generally less than those of recruits sampled in
January (Fig. 3); a result consistent with a December spawning and settlement for Haliotis rubra. However, recruits sampled off Sandpatch in December 1989 had a significantly greater mean shell length than that of recruits collected in December of previous years (by ANOVA, $F_{2,432}=3.2, p<0.001$ ). The mean length of recruits sampled in December 1987 and 1988 was indicative of a post-settlement age of ca $10 \mathrm{~d}$. In contrast, the length distribution of recruits sampled during December 1989 (Sandpatch) indicates that settlement started as early as October that year.

Analyses of variance revealed that the mean length of Haliotis rubra recruits for the 3 populations off Mallacoota was similar for samples collected during December $1987\left(F_{2.467}=0.2, \mathrm{p}=0.15\right)$ but differed for samples collected during December 1988 (mean length $\left.F_{2,523}=4.2, p<0.001\right)$. Fig. 4 shows that mean lengths for recruits (1988 samples) from Sandpatch and Tullaburga Island are similar and greater than those at Bastion Point.

If the post-settlement growth rates are similar between populations, the difference in shell length of recruits sampled during December 1988 suggests that settlement of Haliotis rubra in the Bastion Point population occurred about $10 \mathrm{~d}$ after settlement at Sandpatch or Tullaburga Island. The mean length of recruits sampled in January 1989 from Bastion Point (440 $\mu \mathrm{m})$ suggests a post-settlement age of about $9 \mathrm{~d}$.

Densities of Haliotis rubra recruits in our samples varied from 0 to $12456 \mathrm{~m}^{-2}$. The mean density of recruits sampled off Bastion Point during December 1988 was $1860 \mathrm{~m}^{-2}$ and is orders of magnitude higher than estimates from comparable studies of abalone, for example Prince \& Ford (1985) (0 to $\left.15 \mathrm{~m}^{-2}\right)$, Shepherd \& Turner (1985) (up to $13 \mathrm{~h}^{-1}$ searching time), but comparable with estimates of recruitment by Tanaka et al. (1986)
Fig. 2. Haliotis rubra. Length-frequency distributions of recruits sampled during 1987 in 3 populations: Bastion Point, Sandpatch, and Tullaburga Island

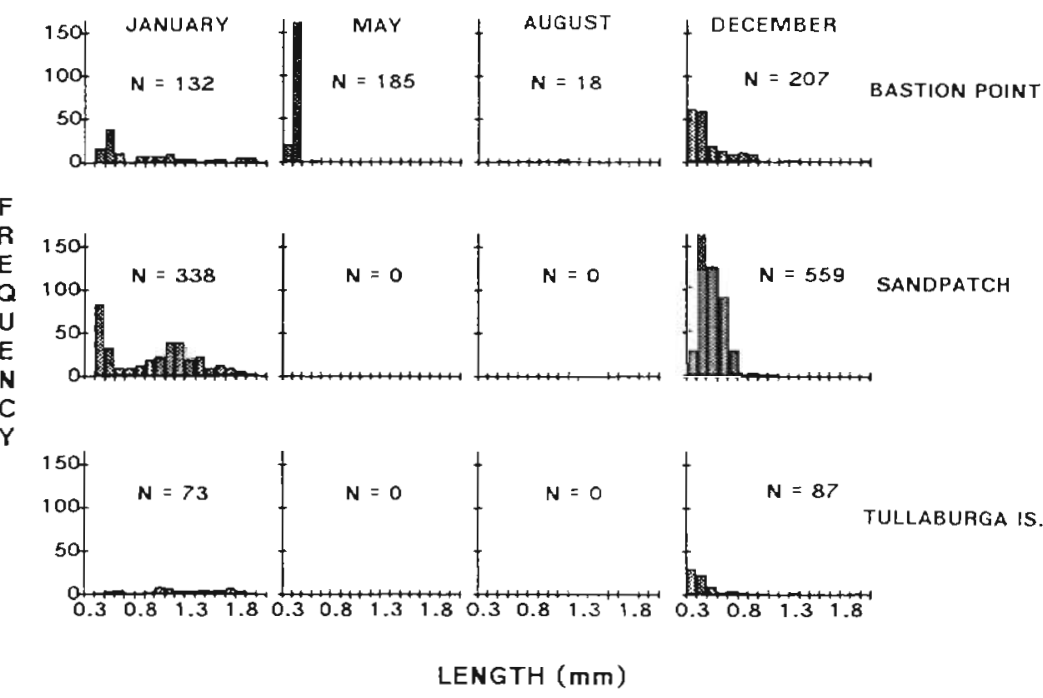




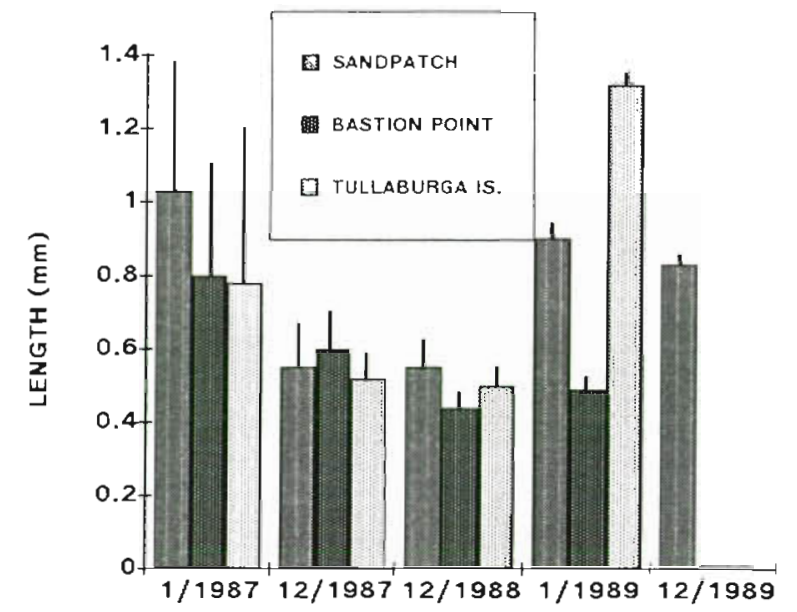

Fig. 3. Haliotis rubra. Mean shell length of recruits sampled on 5 occasions from 3 populations: Sandpatch, Tullaburga Island and Bastion Point. Vertical bars represent standard errors

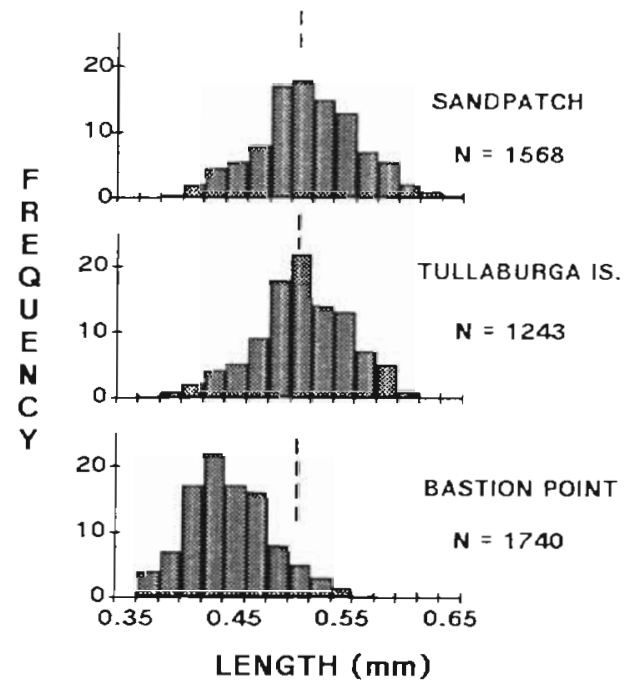

Fig. 4. Haliotis rubra. Length-frequency distributions of recruits from 3 populations: Sandpatch, Tullaburga Island and Bastion Point, sampled during December 1988. Dashed line indicates median frequencies for the Sandpatch and Tullaburga Island populations

A comparison of recruitment of Haliotis rubra in December (the main spawning period) with a 2 -way analysis of variance revealed that the density of recruits varied between years but not between populations (Table 1); estimated densities of recruits in 1988 at Bastion Point and Sandpatch were 2 orders of magnitude greater than that recorded in December 1987. The variability of recruitment within a population was high; replicate counts at one site at Sandpatch ranged from 769 to over 12456 recruits $\mathrm{m}^{-2}$. Such spatial variation in recruitment within a population made identification of between-population variation tenuous.
Table 1. Haliotis rubra. Recruitment variation in 3 populations off Mallacoota. Data are densities $\left(\mathrm{m}^{-2}\right)$ measured in December 1987 and 1988 and are means $\pm \mathrm{SE}$

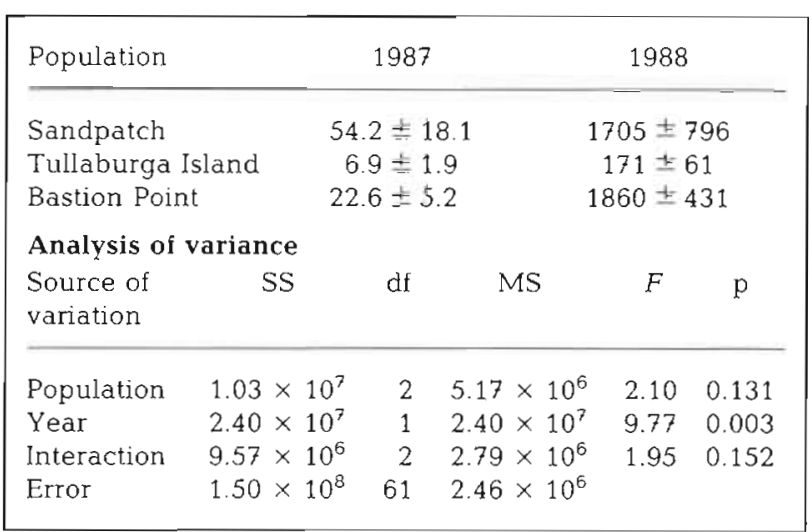

\section{Portland}

Analysis of variance indicated that the mean density of Haliotis rubra recruits was similar between sites at each of the 7 locations surveyed off Portland (ANOVA, $\mathrm{p}>0.28$ ). Data from individual sites were therefore pooled for comparison of recruitment between populations. Analysis of variance revealed that recruitment varied between populations $\left(F_{6,28}=3.4, p=0.013\right.$; Fig. 5). Mean densities of recruits were comparable with estimates derived from Sandpatch (off Mallacoota) during December $1989\left(9.1 \pm 0.5 \mathrm{~m}^{-2}\right)$; mean densities off Portland ranged from 7.2 to $163.4 \mathrm{~m}^{-2}$.

Length-frequency data indicated a size range similar to that for the Mallacoota populations; recruits varied in length from 390 to $2890 \mu \mathrm{m}$. However, in general, the length-frequency distributions of the 7 populations sampled were negatively skewed with most recruits ranging in length from 400 to $700 \mu \mathrm{m}$ (Fig. 6); a size range indicative of recent settlement. Analysis of variance revealed that mean lengths of recruits varied between populations $\left(F_{6.1512}=4.3, \mathrm{p}<0.001\right)$. A pairwise comparison of means by Tukey's HSD test showed that recruits from Cape Bridgewater were smaller than those from Whites Beach and Seal Caves which had similar means (Fig. 6).

The size composition of recruits differed even between neighbouring populations. The length-frequency distribution of recruits from Cape Nelson was unimodal (mean length $655 \mu \mathrm{m}$ ) whereas a mode of larger recruits was apparent in the distribution of recruits from Inside Nelson (median length $1670 \mu \mathrm{m}$; Fig. 7). A comparison of the 2 populations at Horseshoe, separated by about $100 \mathrm{~m}$, revealed that the mean length $( \pm S D)$ of recruits was significantly different $\left(1.15 \pm 0.48 \mathrm{~mm} ; 1.49 \pm 0.66 \mathrm{~mm}\right.$; ANOVA, $F_{1,191}=$ 


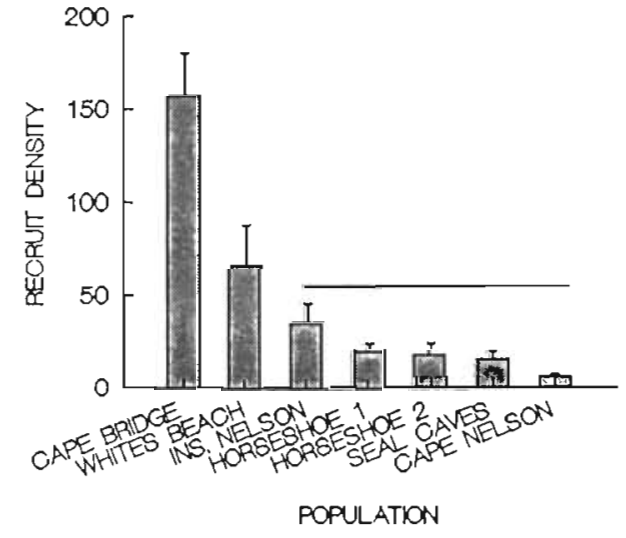

Fig. 5. Haliotis rubra. Comparison of the density of recruits sampled from 7 populations off Portland. Data are means (recruits $\mathrm{m}^{-2}, \mathrm{~N}=5$ ). Vertical bars indicate standard errors for each population. Horizontal bars indicate populations with similar densities (Tukeys HSD test, $p>0.05$ )

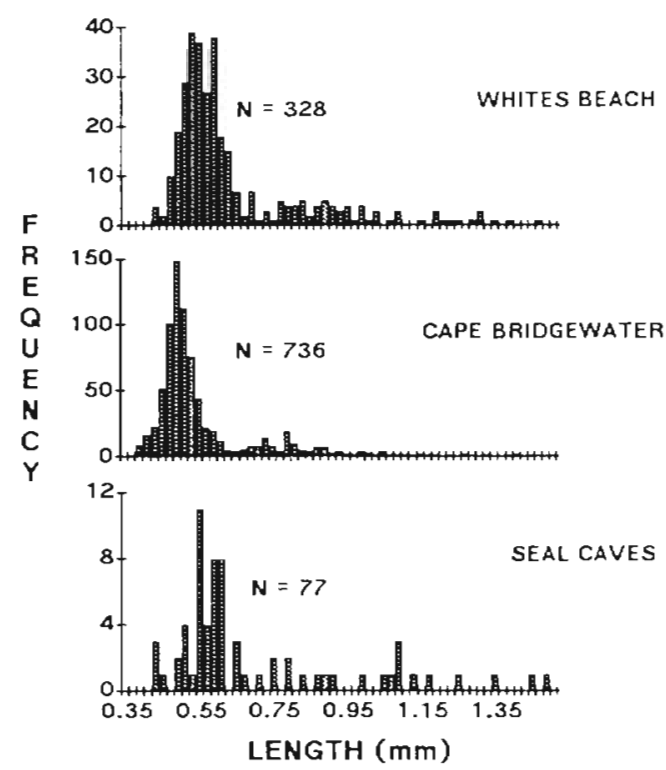

Fig. 6. Haliotis rubra. Length-frequency distribution of recruits sampled from 3 neighbouring populations off Portland: Whites Beach, Cape Bridgewater and Seal Caves

$20.0, p<0.01$ ). Fig. 8 shows a mode of larger recruits at Horseshoe 2 (median length $2370 \mu \mathrm{m}$ ) which were infrequent at Horseshoe 1.

\section{Adult density}

The relative density of adult Haliotis rubra in the 3 populations off Mallacoota were different (means for Sandpatch and Tullaburga Island were similar, ANOVA, $p>0.1$ ) but were similar from year to year for each population (ANOVA, $\mathrm{p}>0.6$ ). Mean densities (ind. $\mathrm{m}^{-2} \pm \mathrm{SE}$ ) of adults were $3.5 \pm 1.5$ for Sandpatch,

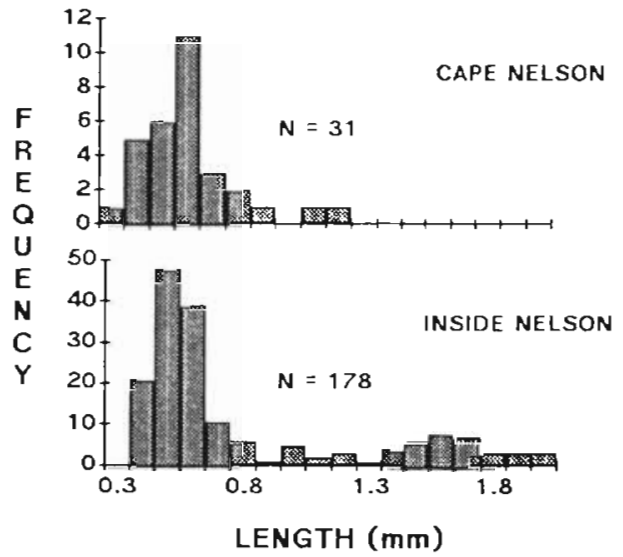

Fig. 7. Haliotis rubra. Comparison of the length-frequency distribution of recruits sampled from 2 neighbouring populations, Cape Nelson and Inside Nelson

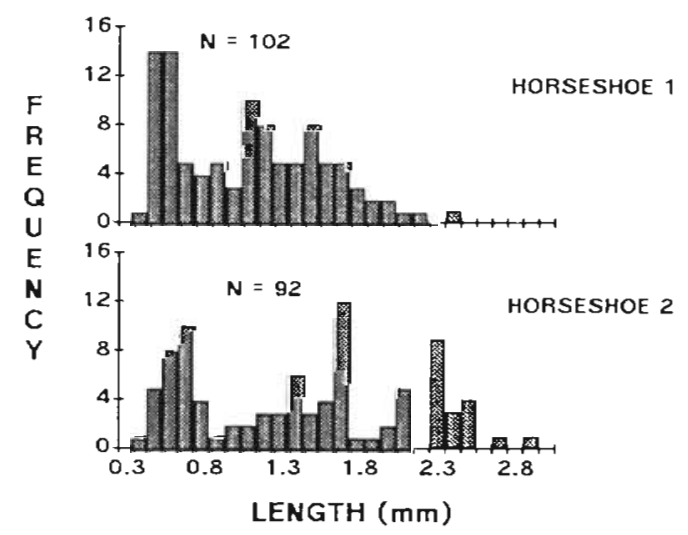

Fig. 8. Haliotis rubra. Comparison of the length-frequency distribution of recruits sampled from 2 neighbouring populations, Horseshoe 1 and Horseshoe 2

$3.4 \pm 1.4$ for Tullaburga Island and $2.5 \pm 0.8$ for Bastion Point. Thus, for each population, recruitment varied independently of adult density; there was no evidence of a stock-recruitment relationship $(\mathrm{N}=7, \mathrm{r}=$ $0.13, p=0.85$ ).

\section{DISCUSSION}

Our surveys show that recruits of Haliotis rubra can be censused soon after settlement; the size of many of the recruits approximated that estimated for metamorphosed larvae of other species of abalone (Ino 1952, Ebert \& Houk 1984). The results also suggest that settlement of $H$. rubra can be dense and episodic; densities of recruits were much higher than those previously reported (Prince \& Ford 1985, Prince et al. 1987) for the species and were comparable to the densities of opportunistic colonizers, such as barnacles, which colonize hard substrata (Denley \& Underwood 1979, Caffey 1985, Connell 1985, Gaines et al. 1985). These findings 
together with our observations of spatial variability in recruitment of $H$. rubra can be explained by the localized dispersal of larvae (Prince et al. 1987 , McShane et al. 1988) as discussed below. Another important finding of our study is that the variation in recruitment was high at constant adult population size.

The density of recruits that we recorded for some populations is consistent with larval 'swarms' remaining close to the habitat of parents but is contrary to statements that abalone larvae are absent near the time of spawning (Breen \& Adkins 1980; see also McShane 1991b). However, abalone larvae are difficult to detect because they are episodically released, relatively shortlived and may be expected to be diffused and dispersed to low concentrations in the open sea (Strathmann 1985, McShane et al. 1988). Larval 'swarms' of passively transported larvae can only exist if retained in eddies or if water currents are sufficiently attenuated such that diffusion and dispersal are minimized (McShane et al. 1988, McShane 1991b)

The most striking result of our study was the large interannual and spatial variation in recruitment of Haliotis rubra. This finding parallels results from studies of other subtidal benthic invertebrates (e.g. Keough \& Downes 1982, Keough 1983, Caffey 1985, Connell 1985, Yoshioka 1986, Fletcher 1987). At Sandpatch, an easterly flowing current forms an eddy on the eastern side of the headland where recruits are concentrated (McShane 1991b); eddies can entrain larvae (Black 1990). At Portland, 2 neighbouring populations of $H$. rubra, Cape Nelson and Inside Nelson, are hydrodynamically isolated; the population at Inside Nelson inhabits a sheltered reef in the lee of an exposed headland (Cape Nelson). Recruits were more dense at the sheltered location, where larvae are more likely to be entrained (McShane et al. 1988), than at Cape Nelson which is subject to the prevailing southwesterly waves. In addition Cape Nelson had fewer kelp beds than the other locations at Portland (P. E. McShane unpubl.). Kelp stands are important in trapping larvae and localising recruitment (Eckman et al. 1989, Duggins et al. 1990), and dense stands of the kelp Phyllospora comosa at Whites Beach and Cape Bridgewater can be expected to entrain larvae. At Horseshoe, a sheltered location, neighbouring populations of $H$. rubra differed in the size composition of recruits. In such an environment, with dense kelp beds and mild water movement, neighbouring populations may be expected to be hydrodynamically isolated resulting in little exchange of larvae. For these reasons we also expected relatively dense settlement at Horseshoe but the relatively large size of the recruits at Horseshoe suggested that settlement had occurred at least a month prior to settlement in the other Portland populations and the recruitment observed would be substantially less than the actual settlement.

The high variability in recruitment of Haliotis rubra may reflect variability in larval abundance, a phenomenon recorded for other species of marine invertebrates (Keough 1983, Gaines et al. 1985, Yoshioka 1986. Gotelli 1987), but, because detection of abalone larvae in their natural habitat is so difficult, this hypothesis has not been tested. Nonetheless, our studies of several $H$. rubra populations near Mallacoota showed that recruitment was regional rather than local. Thus there were 'good' and 'bad' years for recruitment; recruitment was generally high in 1988 and low in 1987 indicating year-to-year variation in exogenous factors.

The size composition of recruits suggested that settlement was episodic and asynchronous between populations. The presence of larger 'modes' of recruits in some populations, for example Horseshoe, and the presence of recruits outside the 'normal' spawning time at Bastion Point indicated that Haliotis rubra settle unpredictably and that settlement was not uniform even between neighbouring populations. Local dispersal of larvae provides an explanation of these results. As an alternate explanation, differences in rates of growth and survival of recruits between populations may have caused the apparent differences in the size composition of recruits between populations. While we cannot reject this latter hypothesis there is little evidence to support it. At Horseshoe, a sheltered site, the 2 populations studied inhabited the same reef complex. Many of the populations of $H$. rubra at Portland were in close proximity and occupied similar habitat. There was no evidence of major differences in community composition, including likely predators, nor was there any evidence of differences in the physiography of the reef which could explain differential survival. At Mallacoota, the 3 populations of $H$. rubra studied were part of similar communities inhabiting reefs similar in depth and topography (McShane et al. 1988).

A stock-recruitment relationship (cf. Ricker 1954, Beverton \& Holt 1957) is an attractive hypothesis to explain variation in recruitment in abalone. McShane et al. (1988) and Prince et al. (1988) showed that recruitment of Haliotis rubra correlated with adult abundance; yet our results show that recruitment within a single population varied enormously from year to year with constant adult abundance. In contrast, Prince et al. (1988), on the basis of results from surveys of several populations, claim a stock-recruitment relationship for $H$. rubra; however they surveyed recruits at least 2 mo after settlement and combined data collected at different times from different populations. The variation in recruitment of benthic invertebrates in general is so high (Yoshioka 1986) that correlations with the abundance of spawning stock are tenuous. 
Not surprisingly stock-recruitment relationships are seldom evident in benthic invertebrate populations (Hancock 1973).

The evidence suggests that events in the early life history are as important in determining the population structure of Haliotis rubra as they are in other species of benthic marine invertebrates. Recruitment varies stochastically. Factors controlling spawning periodicity could contribute to such variation; both aspects would be worthy of further study.

\section{LITERATURE CITED}

Beverton, R. J. H., Holt, S. J. (1957). On the dynamics of exploited fish populations. Fish. Invest. (Lond.) 19: 1-533

Black, K. P. (1990). The relationship of reef hydrodynamics to variations in numbers of planktonic larvae around coral reefs. Proc. 6th Int. Coral Reef Symp

Black, K. P., McShane, P. E. (1990). Influence of surface gravity waves on wind-driven circulation in intermediate depths on an exposed coast. Aust. J. mar. Freshwat Res. 41: 353-363

Breen, P. A., Adkins, B. E. (1980). Spawning in a British Columbia population of northern abalone, Haliotis kamtschatkana. Veliger 23: 177-179

Butman, C. A. (1987). Larval settlement of soft-sediment invertebrates: the spatial scales of patterns explained by active habitat selection and the emerging role of hydrodynamic processes. Oceanogr. mar. Biol. Ann. Rev. 25: $113-165$

Butman, C. A. (1989). Sediment trap experiments on the importance of hydrodynamical processes in distributing settling invertebrate larvae in near-bottom waters. J. exp. mar. Biol. Ecol. 134: 37-88

Caffey, H. M. (1985). Spatial and temporal variation in settlement and recruitment of an intertidal barnacle. Ecol. Monogr. 55: 313-332

Connell, J. H. (1985). The consequences of variation in initialsettlement vs. post-settlement mortality in rocky intertidal communities. J. exp. mar. Biol. Ecol. 93: 11-45

Davis, A. R. (1987). Variation in recruitment of the subtidal colonial ascidean Podoclavella cylindrica (Quoy \& Gaimard): the role of substratum choice and early survival. J. exp. mar. Biol. Ecol. 106: 57-71

Davis, A. R. (1988). Effects of variation in initial settlement on distribution and abundance of Podoclavella moluccensis Sluiter. J. exp. mar. Biol. Ecol. 117: 157-167

Denley, E. J., Underwood, A. J. (1979). Experiments on factors influencing settlement, survival and growth of two species of barnacles in New South Wales. J. exp. mar. Biol. Ecol. 36: 269-293

Duggins, D. O., Eckman, J. E., Sewell, A. T. (1990). Ecology of understory kelp environments. II. Effects of kelps on recruitment of benthic invertebrates. J. exp. mar. Biol. Ecol. 143: $27-45$

Ebert, E. E., Houk, J. L. (1984). Elements and innovations in the cultivation of red abalone, Haliotis rufescens. Aquaculture 39: 375-392

Eckman, J. E., Duggins, D. O., Sewell, A. T. (1989). Ecology of understory kelp environments. I. Effects of kelps on flow and particle transport near the bottom. J. exp. mar. Biol. Ecol. 129: 173-187

Fletcher, W. J. (1987). Interactions among subtidal Australian sea urchins, gastropods, and algae: effects of experimental removals. Ecol. Monogr. 57: 89-109

Gaines, S. D., Roughgarden, J. (1987). Fish in offshore kelp forests affect recruitment to intertidal barnacle populations. Science 235: 479-481

Gaines, S. D., Brown, S., Roughgarden, J. (1985). Spatial variation in larval concentration as a cause of spatial variation in settlement for the barnacle, Balanus glandula. Oecologia (Berl.) 67: 267-273

Garland, C. D., Cooke, S. L., Grant, J. F., McMeekin, T. A. (1985). Ingestion of the bacteria on and the cuticle of crustose (non-articulated) coralline algae by post-larval and juvenile abalone (Haliotis ruber Leach) from Tasmanian waters. J. exp. mar. Biol. Ecol. 91: 137-149

Gerrodette, T. (1981). Dispersal of the solitary coral Balanophylia elegans by demersal planular larvae. Ecology 62: 611-619

Gotelli, N. J. (1987). Spatial and temporal patterns of reproduction, larval settlement, and recruitment of the compound ascidian Aplidium stellatum. Mar. Biol. 94: 45-51

Hamilton, A. L. (1969). A method of separating invertebrates from sediments using longwave ultra-violet light and fluorescent dyes. J. Fish. Res. Bd Can. 26: 1667-1672

Hancock, D. A. (1973). The relationship between stock and recruitment in exploited invertebrates. Rapp. P.-v. Réun. Comm. int. Explor. Mer. 164: 113-131

Hannan, C. A. (1984). Planktonic larvae may act like passive particles in turbulent near-bottom flows. Limnol. Oceanogr. 29: 1108-1116

Ino, T. (1952). Biological studies of the propagation of the Japanese abalone (genus Haliotis). Bull. Tokai Reg. Fish. Res. Lab. 5: 29-102

Keough, M. J. (1983). Patterns of recruitment of sessile invertebrates in two subtidal habitats. J. exp. mar. Biol. Ecol. 66: 213-245

Keough, M. J. (1986). The distribution of a bryozoan on seagrass blades: settlement growth and mortality. Ecology 67 : 846-857

Keough, M. J. (1989). Benthic populations: is recruitment limiting or just fashionable? Proc. 6th Int. Coral Reef Symp.

Keough, M. J., Downes, B. J. (1982). Recruitment of marine invertebrates: the role of active larval choices and early mortality. Oecologia (Berl) 54 : 348-352

Lewin, R. (1986). Supply-side ecology. Science 234: 25-27

McGuinness, K. A., Davis, A. R. (1989). Analysis and interpretation of the recruit-settler relationship. J. exp. mar. Biol. Ecol. 134: 197-202

McShane, P. E. (1991a). Density dependent mortality of recruits of the abalone Haliotis rubra (Mollusca: Gastropoda). Mar. Biol. 109: in press

McShane, P. E. (1991b). Early life history of abalone. In: Shepherd, S. A., Tegner, M. J., Guzman del Proo, S. (eds.) Abalone of the world: biology, fisheries and culture. Blackwell, Oxford

McShane, P. E., Beinssen, K. H. H., Foley, S. (1986). Abalone reefs in Victoria - a resource atlas. Vic. Min. for Cons. For. and Lands M. S. L. Tech. Rep. No. 47, 50 p.

McShane, P. E., Black, K. P., Smith, M. G. (1988). Recruitment processes in Haliotis rubra (Mollusca: Gastropoda) and regional hydrodynamics in southeastern Australia imply localized dispersal of larvae. J. exp. mar. Biol. Ecol. 124: 175-203

McShane, P. E., Smith, M. G. (1988). Measuring recruitment of abalone Haliotis rubra Leach (Gastropoda: Haliotidae) comparison of a novel method with two other methods. Aust. J. mar. Freshwat. Res. 39: 331-336

Prince, J. D., Ford, W. B. (1985). Use of anaesthetic to standar- 
dize efficiency in sampling abalone populations (genus: Haliotis: Mollusca: Gastropoda). Aust. J. mar. Freshwat. Res. 36: 701-706

Prince, J. D., Sellers, T. L., Ford, W. B., Talbot, S. R. (1987) Experimental evidence for limited dispersal of haliotid larvae (genus: Haliotis: Mollusca: Gastropoda). J, exp mar. Biol. Ecol. 106: 243-263

Prince, J. D., Sellers, T. L., Ford, W B., Talbot, S. R. (1988) Confirmation of a relationship between the localized abundance of breeding stock and recruitment for Haliotis rubra Leach (Moliusca: Gastropoda). J. exp. mar. Biol Ecol. 122: 91-104

Ricker, W. E. (1954). Stock and recruitment. J. Fish. Res. Bd Can. 11. 559-623

Rowley, R. J. (1989). Settlement and recruitment of sea urchins (Stroglyocentrotus spp.) in a sea-urchin barren ground and a kelp bed: are populations regulated by settlement or post-settlement processes? Mar. Biol. 100: 485-494

Sellmer, G. P. (1956). A method for the separation of small bivalve molluscs from sediments. Ecology 37: 206

Shepherd, S. A. (1973). Studies on southern Australian abalone (genus Haliotis). I. Ecology of five sympatric species. Aust. J. mar. Freshwat. Res. 24: 217-257

Shepherd, S. A., Turner, J. A. (1985). Studies on southern Australian abalone (genus Haliotis). VI. Habitat preference and abundance and predators of juveniles. J. exp. mar. Biol. Ecol. 93: 285-298

This article was submitted to the editor
Stoner, D. S. (1990). Recruitment of a tropical colonial ascidian: relative importance of pre-settlement vs. post-settlement processes. Ecology 71: 1682-1690

Strathmann, R. R. (1985). Feeding and non-feeding larval development and life-history evolution in marine invertebrates. Ann. Rev. Ecol. Syst. 16: 339-361

Tanaka, K., Tanaka, T., Ishida, O., Oba, T (1986). On the distribution of swimming and deposited larvae of nursery ground of abalone at the southern coast of Chiba prefecture. Bull. Jap. Soc. scient. Fish. 52: 1525-1532

Underwood, A. J., Denley, E. J. (1984). Paradigms, explanations and generalizations in models for the structure of intertidal communities on rocky shores. In: Strong, D. R, Simberloff, D., Abele, L., Thistle, A. B. (eds.) Ecological communities: conceptual issues and evidence. Princeton University Press, Princeton, New Jersey, p. 151-180

Young, C. M. (1989). Larval depletion by ascidians has little effect on settlement of epifauna. Mar. Biol. 102: 481-489

Young, C. M., Chia, F. S. (1982). Factors controlling spatial distribution of the sea cucumber Psolus chitinoides: settling and post-settling behaviour. Mar. Biol. 69: 195-205

Yoshioka, P. M. (1982). Role of planktonic and benthic factors in the population dynamics of the bryozoan Membranipora membranacea. Ecology 63: 457-468

Yoshioka, P. M. (1986). Chaos and recruitment in the bryozoan, Membranipora membranacea. Bull. mar. Sci. 39: $408-417$

Manuscript first received: December 7, 1990

Revised version accepted: April 25, 1991 